\title{
THE SAFETY AND EFFICACY OF ROBOT-ASSISTED STEREOTACTIC BIOPSY FOR BRAIN GLIOMA: EARLIEST INSTITUTIONAL EXPERIENCES AND EVALUATION OF LITERATURE
}

\author{
Krešimir Rotim ${ }^{1,2,3}$, Bruno Splavski1 ${ }^{1,2,3,4}$ and Filip $\operatorname{Vrban}^{1}$ \\ ${ }^{1}$ Department of Neurosurgery, Sestre milosrdnice University Hospital Centre, Zagreb, Croatia; \\ ${ }^{2}$ Josip Juraj Strossmayer University of Osijek, Faculty of Medicine, Osijek, Croatia; \\ ${ }^{3}$ University of Applied Health Sciences, Zagreb, Croatia; \\ ${ }^{4}$ Josip Juraj Strossmayer University of Osijek, Faculty of Dental Medicine and Health, Osijek, Croatia
}

SUMMARY - Robot-assisted brain tumor biopsy is becoming one of the most important innovative technologies in neurosurgical practice. The idea behind its engagement is to advance the safety and efficacy of the biopsy procedure, which is much in demand when planning the management of endocranial tumor pathology. Herein, we provide our earliest institutional experiences in utilizing this mesmerizing technology. Cranial robotic device was employed for stereotactic robot-assisted brain glioma biopsy in three consecutive patients from our series: an anaplastic isocitrate dehydrogenase (IDH) negative astrocytoma (WHO grade III) located in the right trigone region of the periventricular white matter; a low grade diffuse astrocytoma (WHO grade II) of bilateral thalamic region spreading into the right mesencephalic area; and an IDH-wildtype glioblastoma (WHO grade IV) of the right frontal lobe producing a contralateral midline shifting. Robot-assisted tumor biopsy was successfully performed to get tissue samples for histopathologic and immunohistochemical analysis. The adjacent tissue iatrogenic damage of the eloquent cortical areas was minimal, while the immediate postoperative recovery was satisfactory in all patients. In conclusion, considering the preliminary results of our early experiences, robot-assisted tumor biopsy was proven to be a feasible and accurate procedure when surgery for brain glioma was not an option. It may increase safety and precision, without expanding surgical time, being similarly effective when compared to standard stereotactic and manual biopsy. Using this method to provide accurate sampling for histopathologic and immunohistochemical analysis is a safe and easy way to determine management strategies and outcome of different types of brain glioma.

Key words: Neurosurgery; Brain glioma; Robotics; Stereotactic biopsy

\section{Introduction}

Robot-assisted neurosurgery is recently becoming one of the most important innovative technologies in

Correspondence to: Bruno Splavski, $M D, P h D$, Department of Neurosurgery, Sestre milosrdnice University Hospital Centre, Vinogradska c. 29, HR-10000 Zagreb, Croatia

E-mail: splavuno@gmail.com

Received May 2, 2021, accepted May 27, 2021 surgical practice. The idea behind its introduction is to further advance the safety, efficacy and precision of neurosurgical procedures, which are much in demand when dealing with endocranial tumor pathology, where management outcome of such a delicate process is concerned. The principal goal of this most modern technology is to supplement contemporary neurosurgical operative armamentarium with a safe device that may methodically enhance accuracy and precision in the operating room, which would not be possible 
otherwise. Moreover, robotic biopsy also facilitates careful preoperative planning ${ }^{1}$.

Topics in effective brain glioma surgery include determining the exact lesion location, and assuring optimal approach to the surgical target in relation to the patient's unique anatomy, enabling tumor resection with a high degree of accuracy and procedure control to minimize adjacent healthy brain tissue damage. That has been the aim of surgery ever since 1908, when Horsley and Clarke defined stereotactic calculation based on a coordinate system and created a frame fixed to the skull, which would accurately locate any intracranial point in three dimensions $(3 \mathrm{D})^{2}$.

Frame-based stereotactic biopsy, as well as frameless image-guided one using scalp fiducial markers, have been considered the gold standard for brain biopsies regardless of their limitations associated with device flexibility, stability, accuracy, and biopsy needle positioning. Nonetheless, robot-assisted stereotactic biopsy could provide advantages over these two techniques avoiding their downside effects ${ }^{3}$. It exemplifies one of the earliest and finest uses of neurosurgical robotics being accepted by the scientific neurosurgical community in recent times ${ }^{4}$. It was initially employed in 1985 to perform stereotactic biopsy of a deep-seated brain lesion as the first-ever surgical robot procedure ${ }^{5}$. Since then, navigation and robotics in neurosurgery have improved very much, being successfully employed on a broader basis worldwide.

A robotic probe is the main tool for robot-assisted stereotactic tumor biopsy. It is interfaced with a computerized tomographic (CT) scanner and mounted at its end effector. Once the target is identified, a simple command moves the robot to a position pointing toward the target, which is a faster and more accurate procedure in comparison to the manually adjustable stereotactic frame biopsy. Appropriate preoperative imaging provides an anatomical roadmap to guide the biopsy needle to the exact target ${ }^{6}$. It is obvious that the above mentioned accuracy and safety, which is achieved by proper robot calibration, is the most essential benefit of such a procedure. Additionally, characteristics of robotic technology also include a combination of agility, robustness, resilience, and precision, which have been unseen previously.

A tendency of robot miniaturization, cost-effectiveness, mass production, and increasing procedure precision will distinguish prosperous robotic technolo- gies of the future, which will advance modern neurosurgical practice even further ${ }^{7}$.

Herein, we provide preliminary results of our earliest institutional experiences in utilizing this mesmerizing technology for stereotactic biopsy of brain glioma, and evaluate the literature dealing with this most modern operative tool.

\section{Illustrative Case Series}

Medtronic Stealth Autoguide cranial robotic device was employed for stereotactic robot-assisted tumor biopsy in all patients from our series. All samples were positive for tumor tissue, which was sent for histopathologic and immunohistochemical (IMH) analysis. The adjacent brain tissue iatrogenic damage to the eloquent cortical areas was minimal, while the immediate postoperative recovery was satisfactory in all of them.

\section{Case 1}

A 74-year-old female patient was admitted to the hospital as an emergency due to a sudden attack of epileptic seizure experienced for the first time in her life. A left-sided moderate motor weakness was observed. She was referred to urgent contrast magnetic resonance imaging (MRI) of the brain, which revealed a space occupying, deep-seated, expansive tumor lesion in the right trigone region of the periventricular white matter with perifocal edema and compression of the occipital horn of the right lateral ventricle (Fig. $1 \mathrm{~A}-\mathrm{C}$ ).

She was scheduled for robot-assisted tumor biopsy via the right temporal gyrus incision, which was chosen as the safest optimal surgical approach. The exact tumor location, the trajectory and end point were determined by navigation system, and the robotic probe was mounted at its end effector and positioned pointing toward the target, allowing the robot to move on after receiving a simple command. Following trephination of the right temporal bone and cortical incision, five samples of the tumor tissue were collected by the robotic probe and sent for histopathologic and IMH examination identifying the tumor as an anaplastic, isocitrate dehydrogenase (IDH) negative astrocytoma (WHO grade III).

Immediate postoperative course and $\mathrm{CT}$ brain scanning were uneventful. Native postoperative brain 

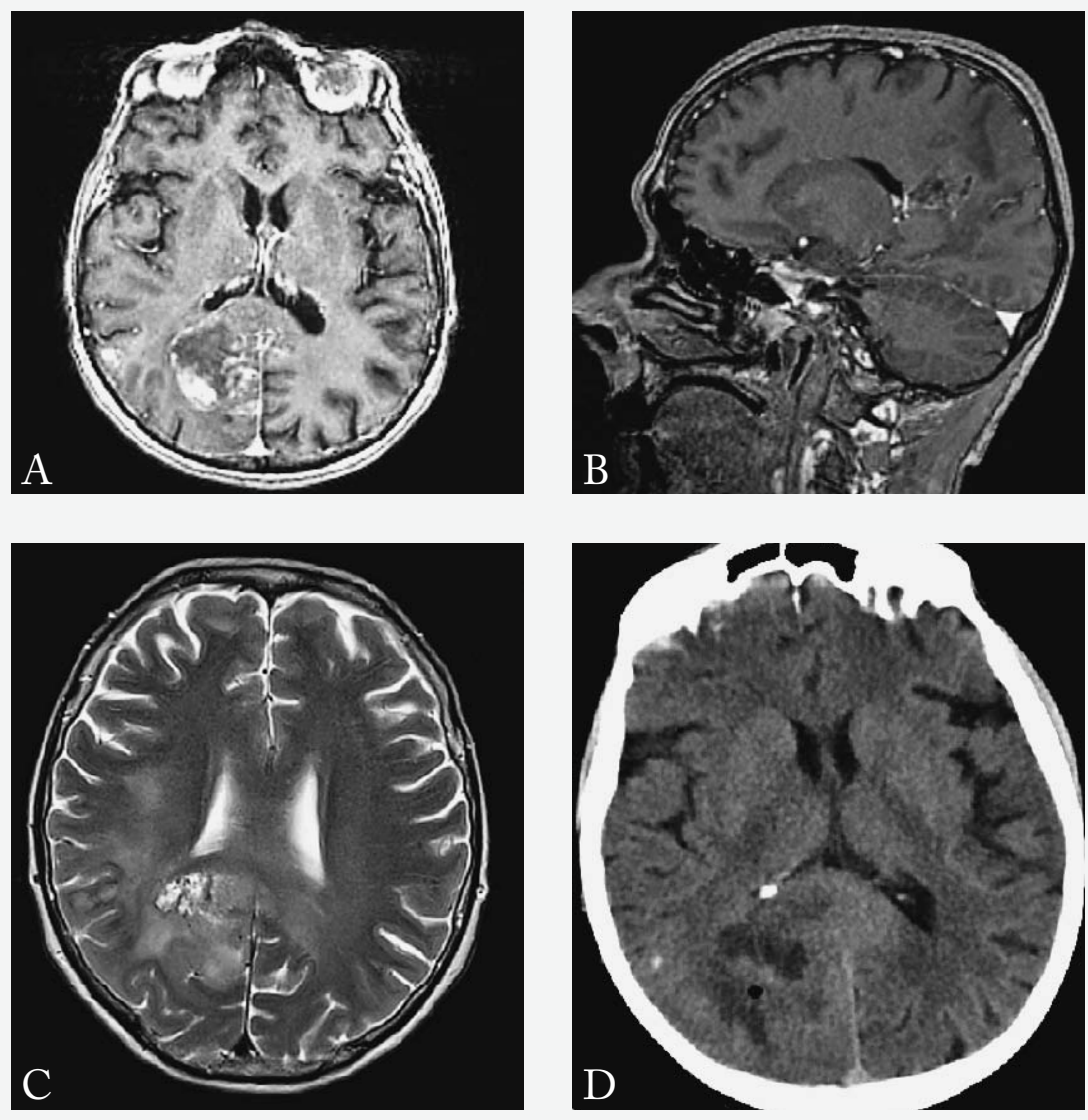

Fig. 1. Axial view of T1-weighted contrast-enhanced magnetic resonance imaging (MRI) of the brain revealing a space occupying, deep-seated, expansive tumor lesion in the right trigone region of the periventricular white matter $(A)$; sagittal MRI reformation confirming the trigonal periventricular tumor (B); axial view of T2weighted brain MRI depicting solid tumor lesion in the right trigone region with perifocal edema and compression of the occipital horn of the right lateral ventricle (C); native postoperative brain axial computed tomography $(C T)$ scan identifying a drop of endocranial air at the site of tumor biopsy (D).

axial CT scan identified a drop of endocranial air at the site of tumor biopsy (Fig. $1 \mathrm{D})$.

The patient was discharged without progression of neurological deficit and with no seizures observed. Further oncologic treatment was advised, as well as physical therapy.

\section{Case 2}

A 66-year-old male patient presented with headache, dizziness, and mental disorientation having no major neurological deficit. Upon hospital admission, neuroradiology diagnostics was done. Native and contrast enhanced MRI depicted bilateral periventricular thalamic mass lesions spreading into the right dorsal mesencephalic region and causing almost complete obstruction of the third ventricle and edema of the right temporal lobe (Fig. $2 \mathrm{~A}, \mathrm{~B}$ ).

Robot-assisted tumor biopsy via the right parietal bone burr holing was performed. The precise tumor location, the trajectory, and entry and target points were defined using the neuronavigation system, and four samples of the tumor tissue were collected by the robotic probe via cortical incision. Two additional tissue samples were taken from a distance of $5 \mathrm{~mm}$ and $10 \mathrm{~mm}$ above the target point. Histopathologic and IMH examination identified the tumor as a low grade 

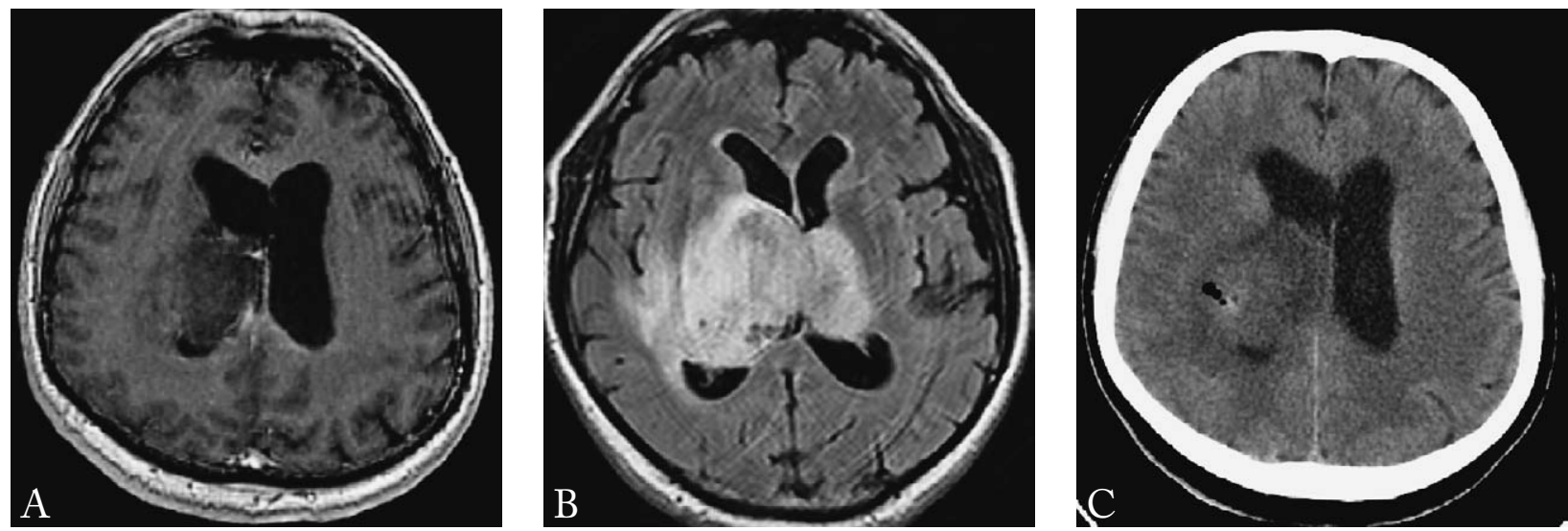

Fig. 2. Native axial brain T1-weighted magnetic resonance imaging (MRI) depicting a periventricular mass lesion of the right thalamic region with compression of the third ventricle $(A)$; contrast enhanced axial brain T1-weighted MRI depicting bilateral periventricular thalamic mass lesions spreading into the right dorsal mesencephalic region and causing almost complete obstruction of the third ventricle and edema of the right temporal lobe (B); native postoperative brain axial computed tomography scan detecting a globule of endocranial air at the tumor biopsy site $(C)$.
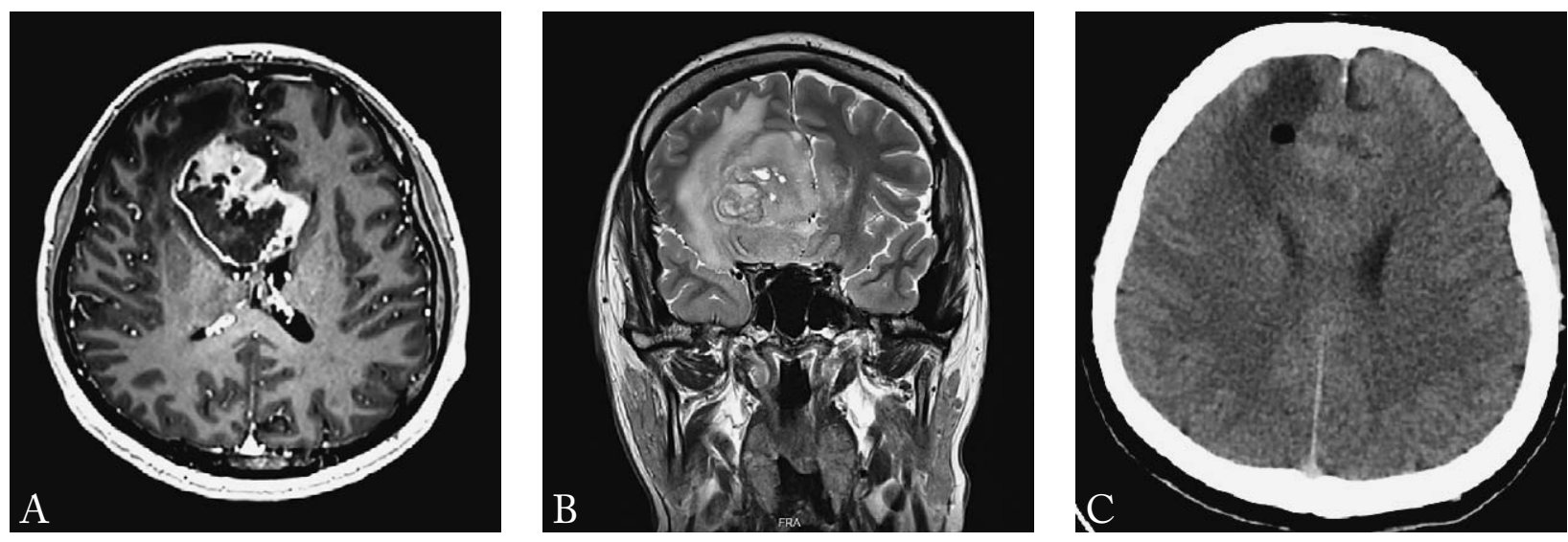

Fig. 3. Contrast enhanced axial T1-weighted brain magnetic resonance imaging (MRI) revealing a parasagittal expansive, partially solid and partially cystic process of the right frontal lobe with a huge perifocal edema compressing frontal horn of the right lateral ventricle and producing contralateral midline shifting $(A)$; coronal T1-weighted reformation of the brain $M R I$ confirming a marked midline shift due to tumor enlargement (B); postoperative native axial computed tomography brain scan detecting a bubble of air at the location of tumor biopsy $(C)$.

diffuse astrocytoma (WHO grade II) having low proliferative activity of tumor cells (Ki-67 2\%). Native postoperative brain axial CT scan detected a globule of endocranial air at the tumor biopsy site (Fig. 2 C).

The patient was discharged from the hospital having minor motor weakness (hemiparesis) of the left limbs. Additional oncologic treatment and radiological follow-up at six months, as well as physical therapy were recommended.

\section{Case 3}

A 41-year-old male patient presented with heavy headaches but without neurological deficit. Contrast enhanced brain MRI revealed a parasagittal expansive, partially solid and partially cystic process of the right frontal lobe with a huge perifocal edema compressing frontal horn of the right lateral ventricle and producing contralateral midline shifting due to tumor enlargement (Fig. $3 \mathrm{~A}, \mathrm{~B}$ ). 
The right frontal bone burr holing was performed, followed by robot-assisted corticotomy and tumor biopsy. The neuronavigation system was employed for accurate tumor location, identifying the trajectory, as well as entry and target points. Four cylindrical tumor tissue samples were obtained using the robotic biopsy needle. The results of histopathologic and IMH analysis specified the tumor as an IDH-wildtype glioblastoma (WHO grade IV).

Postoperative native axial CT brain scan detected a bubble of air at the location of tumor biopsy (Fig. $3 \mathrm{C}$ ).

The patient was discharged from the hospital without neurological deficit. Supplementary oncologic treatment and early radiological follow-up at one month were required as obligatory.

\section{Discussion}

In this paper, we present the initial experiences of robot-assisted stereotactic tumor biopsy we have gained while treating selected brain glioma patients using a cranial robotic device and exemplifying the effectiveness of this technique.

Operational navigation systems in neurosurgery, combined with real-time microscopic visualization, have been developed and refined over the last three decades, continuing to evolve in precision, efficacy, and ergonomics ever since ${ }^{8,9}$. For spatial registration of CT image data from fiducial markers on the scalp and their integration into the operating microscope, a specific computer-based system has been developed without requiring a stereotaxic frame ${ }^{10}$. Nevertheless, intraoperative MRI can also be used for stereotactic tumor biopsy in a regular neurosurgical operating environment ${ }^{11}$. Nowadays, similar systems have gained a pivotal role during cranial and spinal surgeries to facilitate safer and more accurate, minimally invasive procedures, as well as to provide the best possible approaches and less time-consuming interventions ${ }^{12}$. Hence, the majority of brain tumor biopsies are now executed using a frameless navigation-guided automated $\mathrm{arm}^{13}$.

Modern surgical navigation platforms are designed to be compatible with various intraoperative imaging modalities ${ }^{14,15}$, to avoid possible disparity between the preoperatively acquired images and the intraoperative anatomy ${ }^{16,17}$. Therefore, a rigid skull fixation robot-assisted stereotactic biopsy has gained prominence lately. Accordingly, we have recently tried such a technique in three consecutive patients from our series who underwent brain glioma biopsy.

Anaplastic IDH negative astrocytoma was sequenced in the 74-year-old female patient with deepseated tumor of the right trigone region. The isocitrate dehydrogenase mutation status has greater prognostic relevance than histologic diagnosis ${ }^{18}$, indicating that much of the poor prognostic significance of the advanced patient age is due to the absence of IDH mutations. Hence, patients with anaplastic gliomas harboring IDH mutations seem to fare much better than those without such a mutation in their tumors ${ }^{19}$.

Histopathologic and IMH sampling of tumor tissue in the 66-year-old male patient with bilateral periventricular thalamic mass spreading into the right dorsal mesencephalic region identified the tumor as a low grade diffuse astrocytoma. Proliferative activity of tumor cells assessed by the expression of Ki-67 nucleolar protein was $2 \%$, indicating low activity and better prognosis. This protein has been widely used as a proliferation marker for human tumor cells for decades ${ }^{20}$.

Histopathologic specimen and IMH analysis of a huge tumor of the right frontal lobe in the 41-year-old male patient specified the tumor as IDH-wildtype glioblastoma. The absence of IDH mutations indicated the most malignant glioma type (WHO grade IV), having the worst prognosis despite the patient's younger age. Although the IDH genes are mutated in the majority of grade II and III astrocytomas, they are rarely mutated in primary glioblastomas. Therefore, IDH status may unquestionably define biologically different subgroups of brain gliomas ${ }^{21}$, which is of great prognostic importance ${ }^{22}$, but also has a strong implication on therapeutic protocol selection.

Evaluating relevant literature, the efficacy of robotassisted brain tumor biopsy, navigated neuroendoscopy, epilepsy electroencephalography (EEG) electrode placement, and ventricular catheter placement were confirmed $^{23-31}$. Robot-assisted procedures in children also appear to be feasible and safe, particularly for deep-seated tumors such as intrinsic pontine gliomas $^{32-34}$. Such systems minimize movement and increase stability while bone drilling, perform accurate skin and cortical incision placement, and specify drilling depth based on measurement of the skull thickness, enabling real-time visualization ${ }^{35}$. Several studies have reported a $95 \%$ up to $100 \%$ diagnostic accuracy from robot-assisted brain biopsy ${ }^{9,13,36}$, resulting in con- 
siderably lower target errors when compared to standard manual brain biopsy techniques ${ }^{37}$, showing markedly shorter median surgical time, and evidently lower

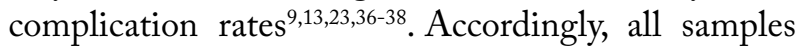
were positive for tumor tissue, the iatrogenic cortical damage was minimal, and no procedure-related shortterm complications were recorded in the series of our patients.

Robots integrated with neuronavigation system and equipped with a specially designed artificial intelligence will probably become integral part of neurosurgical armamentarium in the near future, while telerobotics will enable remote performance of neurosurgical procedures at distant locations ${ }^{8}$. Hence, trends of growing in neurosurgical robotics are more likely to carry on further ${ }^{39}$. However, since operational costs of robotic procedures are generally higher than customary neurosurgical methods ${ }^{39}$, broader availability of this technology will remain questionable. Since the speed of the robotic movements is still relatively slow ${ }^{40}$, it is another technical obstacle, which needs to be resolved before wider accessibility of such equipment is obtained.

In conclusion, according to our initial experiences and preliminary results, frameless robotic-assisted tumor biopsy technique seems to be a safe, accurate and feasible procedure when surgery for brain glioma is not an option. Such a technique may intensify precision without prolonging procedural time, being similarly operational when matched to the standard stereotactic and manual biopsy. Understanding tumor morbidity may also be enhanced by adopting this method, since providing accurate specimen for histopathologic and immunohistochemical analysis is a safe and easy way to determine management strategies and outcome of different types of brain glioma.

Supplementary clinical trials on a broader sample are essential to verify the safety and efficacy of the technique further.

\section{References}

1. Bekelis K, Radwan TA, Desai A, Roberts DW. Frameless robotically targeted stereotactic brain biopsy: feasibility, diagnostic yield, and safety. J Neurosurg. 2012;116(5):1002-6. doi: 10.3171/2012.1.JNS111746.

2. Horsley V, Clarke RH. The structure and functions of the cerebellum examined by a new method. Brain. 1908;31:45-124.
3. Grimm F, Naros G, Gutenberg A, Keric N, Giese A, Gharabaghi A. Blurring the boundaries between frame-based and frameless stereotaxy: feasibility study for brain biopsies performed with the use of a head-mounted robot. J Neurosurg. 2015; 123:737-42. doi: 10.3171/2014.12.JNS141781.

4. Marcus HJ, Vakharia VN, Ourselin S, Duncan J, Tisdall M, Aquilina K. Robot-assisted stereotactic brain biopsy: systematic review and bibliometric analysis. Childs Nerv Syst. 2018; 34(7):1299-309. doi: 10.1007/s00381-018-3821-y.

5. Bagga V, Bhattacharyya D. Robotics in neurosurgery. Ann R Coll Surg Engl. 2018;100(6 Suppl):23-6. doi: 10.1308/rcsann. supp1.19.

6. Siepel FJ, Maris B, Welleweerd MK, Groenhuis V, Fiorini P, Stramigioli S. Needle and biopsy robots: a review. Curr Robot Rep. 2021;2:73-84. doi: 10.1007/s43154-020-00042-1.

7. Fomenko A, Serletis D. Robotic stereotaxy in cranial neurosurgery: a qualitative systematic review. Neurosurgery. 2018;83(4): 642-50. doi: 10.1093/neuros/nyx576.

8. Enchev Y. Neuronavigation: geneology, reality, and prospects. Neurosurg Focus. 2009;27(3):E11. doi: 10.3171/2009.6. FOCUS09109.

9. Legnani FG, Franzini A, Mattei L, Saladino A, Casali C, Prada $\mathrm{F}$, et al. Image-guided biopsy of intracranial lesions with a small robotic device (iSYS1): a prospective, exploratory pilot study. Oper Neurosurg. 2019;17(4):403-12.doi: 10.1093/ons/opy411.

10. Roberts DW, Strohbehn JW, Hatch JF, Murray W, Kettenberger $\mathrm{H}$. A frameless stereotaxic integration of computerized tomographic imaging and the operating microscope. J Neurosurg. 1986;65:545-9. doi: 10.3171/jns.1986.65.4.0545.

11. Schulder M, Spiro D. Intraoperative MRI for stereotactic biopsy. Acta Neurochir (Wien) Suppl. 2011;109:81-7. doi: 10.1007/978-3-211-99651-5_13.

12. Guha D, Jakubovic R, Gupta S, Alotaibi NM, Cadotte D, da Costa LB, et al. Spinal intraoperative three-dimensional navigation: correlation between clinical and absolute engineering accuracy. Spine J. 2017;17(4):489-98. doi: 10.1016/j.spinee. 2016.10.020.

13. Minchev G, Kronreif G, Ptacek W, Kettenbach J, Micko A, Wurzer A, et al. Frameless stereotactic brain biopsies: comparison of minimally invasive robot-guided and manual arm-based technique. Oper Neurosurg. 2020;19(3):292-301. https://doi. org/10.1093/ons/opaa123.

14. Wang A, Tenner M, Tobias M, Mohan A, Kim D, Tandon A. A novel approach using electromagnetic neuronavigation and a flexible neuroendoscope for placement of Ommaya reservoirs. World Neurosurg. 2016;96:195-201. doi: 10.1016/j.wneu.2016. 08.127.

15. Markowitz D, Lin D, Salas S, Kohn N, Schulder M. Compact intraoperative MRI: stereotactic accuracy and future directions. Stereotact Funct Neurosurg. 2017;95(3):197-204. doi: 10.1159 /000475673.

16. Mohyeldin A, Elder JB. Stereotactic biopsy platforms with intraoperative imaging guidance. Neurosurg Clin North Am. 2017;28(4):465-75. doi: 10.1016/j.nec.2017.05.002. 
17. Servello D, Zekaj E, Saleh C, Pacchetti C, Porta M. The pros and cons of intraoperative $\mathrm{CT}$ scan in evaluation of deep brain stimulation lead implantation: a retrospective study. Surg Neurol Int. 2016;7(20):S551-S556. doi: 10.4103/21527806.187534

18. Hartmann C, Hentschel B, Wick W, Capper D, Felsberg J, Simon $\mathrm{M}$, et al. Patients with IDH1 wild type anaplastic astrocytomas exhibit worse prognosis than IDH1-mutated glioblastomas, and IDH1 mutation status accounts for the unfavorable prognostic effect of higher age: implications for classification of gliomas. Acta Neuropathol. 2010;120(6):707-18. doi: 10.1007/ s00401-010-0781-z.

19. Hartmann C, Meyer J, Balss J, Capper D, Mueller W, Christians A, et al. Type and frequency of IDH1 and IDH2 mutations are related to astrocytic and oligodendroglial differentiation and age: a study of 1,010 diffuse gliomas. Acta Neuropathol. 2009;118(4):469-74. doi: 10.1007/s00401-009-0561-9.

20. Sun X, Kaufman PD. Ki-67: more than a proliferation marker. Chromosoma. 2018;127(2):175-86. doi: 10.1007/s00412-0180659-8.

21. Ichimura K. Molecular pathogenesis of IDH mutations in gliomas. Brain Tumor Pathol. 2012;29(3):131-9. doi: 10.1007/ s10014-012-0090-4.

22. Lee KS, Choe G, Nam KH, Seo AN, Yun S, Kim KJ, et al. Immunohistochemical classification of primary and secondary glioblastomas. Korean J Pathol. 2013;47(6):541-8. doi:10.4132/ KoreanJPathol.2013.47.6.541.

23. Dorfer C, Minchev G, Czech T, Stefanits H, Feucht M, Pataraia $\mathrm{E}$, et al. A novel miniature robotic device for frameless implantation of depth electrodes in refractory epilepsy. J Neurosurg. 2017;126(5):1622-8. doi: 10.3171/2016.5.JNS16388.

24. Hayhurst C, Beems T, Jenkinson MD, Byrne P, Clark S, Kandasamy $\mathrm{J}$, et al. Effect of electromagnetic-navigated shunt placement on failure rates: a prospective multicenter study. J Neurosurg. 2010;113(6):1273-8. doi: 10.3171/2010.3.JNS 091237.

25. Karsy M, Abou-Al-Shaar H, Bowers CA, Schmidt RH. Treatment of idiopathic intracranial hypertension via stereotactic placement of biventriculoperitoneal shunts. J Neurosurg. 2018; 130(1):136-44. doi: 10.3171/2017.8.JNS162927.

26. Levitt MR, O’Neill BR, Ishak GE, Khanna PC, Temkin NR, Ellenbogen RG, et al. Image-guided cerebrospinal fluid shunting in children: catheter accuracy and shunt survival. J Neurosurg Pediatr.2012;10(2):112-7. doi: 10.3171/2012.3.PEDS122.

27. Miller BA, Salehi A, Limbrick DD Jr, Smyth MD. Applications of a robotic stereotactic arm for pediatric epilepsy and neurooncology surgery. J Neurosurg Pediatr. 2017;20(4): 364-70. doi: 10.3171/2017.5.PEDS1782.

28. Spyrantis A, Cattani A, Woebbecke T, Konczalla J, Strzelczyk $\mathrm{A}$, Rosenow F, et al. Electrode placement accuracy in robotassisted epilepsy surgery: a comparison of different referencing techniques including frame-based CT versus facial laser scan based on CT or MRI. Epilepsy Behav. 2019;91:38-47. doi: 10.1016/j.yebeh.2018.11.002.
29. Wilson TJ, Stetler WRJ, Al-Holou WN, Sullivan SE. Comparison of the accuracy of ventricular catheter placement using freehand placement, ultrasonic guidance, and stereotactic neuronavigation. J Neurosurg. 2013;119(1):66-70. doi: 10.3171/ 2012.11.JNS111384.

30. Zimmermann M, Krishnan R, Raabe A, Seifert V. Robot assisted navigated neuroendoscopy. Neurosurgery. 2002;51: 1446-51.

31. Zimmermann M, Krishnan R, Raabe A, Seifert V. Robot-assisted navigated endoscopic ventriculostomy: implementation of a new technology and first clinical results. Acta Neurochir (Wien). 2004;146(7):697-704. doi: 10.1007/s00701-0040267-7.

32. Carai A, Mastronuzzi A, De Benedictis A, Messina R, Cacchione A, Miele E, et al. Robot-assisted stereotactic biopsy of diffuse intrinsic pontine glioma: a single-center experience. World Neurosurg. 2017;101:584-8. doi: 10.1016/j.wneu.2017. 02.088 .

33. Dawes W, Marcus HJ, Tisdall M, Aquilina K. Robot-assisted stereotactic brainstem biopsy in children: prospective cohort study. J Robot Surg. 2019;13(4):575-9. doi: 10.1007/s11701018-0899-x.

34. De Benedictis A, Trezza A, Carai A, Genovese E, Procaccini E, Messina R, et al. Robot-assisted procedures in pediatric neurosurgery. Neurosurg Focus. 2017;42:E7. doi: 10.3171/2017.2. FOCUS16579.

35. Matsushima K, Komune N, Matsuo S, Kohno M. Microsurgical and endoscopic anatomy for intradural temporal bone drilling and applications of the electromagnetic navigation system: various extensions of the retrosigmoid approach. World Neurosurg. 2017;103:620-30. doi: 10.1016/j.wneu.2017.04.079.

36. Minchev G, Kronreif G, Martínez-Moreno M, Dorfer C, Micko A, Mert A, et al. A novel miniature robotic guidance device for stereotactic neurosurgical interventions: preliminary experience with the iSYS1 robot. J Neurosurg. 2017;126(3): 985-96. doi: 10.3171/2016.1.JNS152005.

37. Minchev G, Kronreif G, Ptacek W, Dorfer C, Micko A, Maschke $\mathrm{S}$, et al. A novel robot-guided minimally invasive technique for brain tumor biopsies. J Neurosurg. 2019;132 (1):150-8. doi: 10.3171/2018.8.JNS182096.

38. Wolfsberger S, Minchev G, Kronreif G, Widhalm G, Maschke $\mathrm{S}$, Micko A, et al. Development of a miniaturized robotic platform for stereotactic neurosurgery: experience with Stealth AutoGuide from the first series of 133 patients. Neurosurgery. 2018;65(CN_suppl_1):96. doi: 10.1093/neuros/nyy303.146.

39. Smith JA, Jivraj J, Wong R, Yang V. 30 years of neurosurgical robots: review and trends for manipulators and associated navigational systems. Ann Biomed Eng. 2016;44(4):836-46. doi: 10.1007/s10439-015-1475-4.

40. Shah J, Vyas A, Vyas D. The history of robotics in surgical specialties. Am J Robot Surg. 2014;1(1):12-20. doi: 10.1166/ ajrs.2014.1006. 
Sažetak

\section{SIGURNOST I UČINKOVITOST ROBOTOM POTPOMOGNUTE STEREOTAKSIJSKE BIOPSIJE GLIOMSKIH TUMORA MOZGA: RANA INSTITUCIJSKA ISKUSTVA I VREDNOVANJE LITERATURE}

\section{K. Rotim, B. Splavski F. Vrban}

Robotom potpomognuta tumorska biopsija postaje jednom od najvažnijih inovativnih tehnologija u neurokirurškom radu. Razlog njezine uporabe nalazi se u daljnjem poboljšanju sigurnosti, učinkovitosti i preciznosti biopsijske metode koja je osobito značajna u planiranju opskrbe endokranijske tumorske patologije. Ovim radom donosimo prva institucijska iskustva u primjeni ove začudne tehnologije pri biopsiji gliomskih tumora mozga. Kranijski robotički uređaj korišten je pri stereotaksijskoj robotom potpomognutoj tumorskoj biopsiji u tri susljedna slučaja iz naše serije, koja je uspješno učinjena radi uzimanja uzorka tumorskoga tkiva za patohistološku i imunohistokemijsku dijagnostiku u bolesnice s anaplastičkim izocitrat dehidrogenaza (IDH) negativnim astrocitomom (SZO st. III.) smještenim u periventrukulskoj bijeloj tvari desnoga trigonuma, u bolesnika s difuznim astrocitomom niskoga stupnja malignosti (SZO st. II.) smještenim obostrano u talamičkom području sa širenjem u desni mezencefalon, kao i u bolesnika s IDH-wildtype glioblastomom (SZO st. IV.) desnog čeonog režnja s pomakom središnjih tvorba. Jatrogena lezija pripadajućeg elokventnog moždanog korteksa bila je minimalna, dok je neposredni poslijeoperacijski oporavak bio uspješan u svih bolesnika. Uzimajući u obzir preliminarne rezultate našega početnog iskustva, zaključujemo kako je robotom potpomognuta tumorska biopsija dokazano izvodljiva i primjerena metoda u kirurgiji gliomskih tumora mozga kojom se može poboljšati sigurnost i preciznost bez produljenja vremena operacije, a koja je podjednako učinkovita u usporedbi sa standardnom stereotaksijskom i manualnom biopsijom. Uporaba navedene metode omogućuje precizno uzorkovanje tumorskoga tkiva za patohistološku i imunohistokemijsku analizu na siguran i lak način, što doprinosi odabiru strategije liječenja i predviđanju ishoda različitih tipova gliomskih tumora mozga.

Ključne riječi: Neurokirurgija; Gliomski tumor mozga; Robotika; Stereotaksijska biopsija 